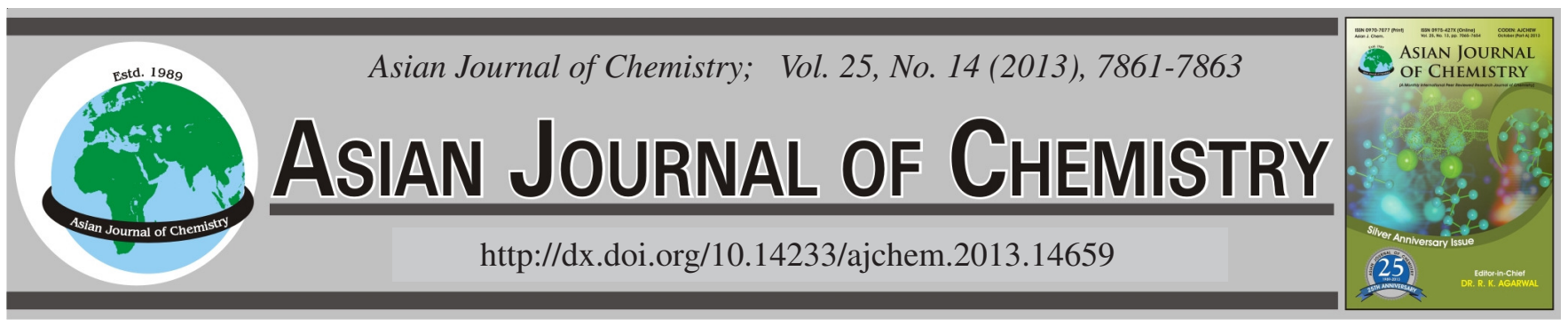

\title{
Study on Volatile Components of Butterfly Nectar Plants and Host Plants
}

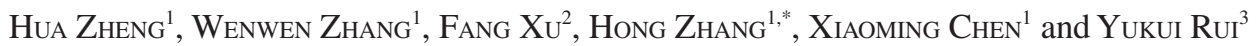

\author{
${ }^{1}$ Research Institute of Resources Insects, Chinese Academy of Forestry, Kunming 650224, P.R. China \\ ${ }^{2}$ Analytical and Testing Center, Beijing Forestry University, Beijing 100083, P.R. China \\ ${ }^{3}$ College of Resources and Environmental Sciences, China Agricultural University, Beijing 100193, P.R. China
}

*Corresponding author: Fax: +86 871 63861466; Tel: +86 871 63860021; E-mail: kmzhhong@163.com

\begin{abstract}
Volatile components of butterfly nectar plants, Lantana camara L., Vitex trifolia L. and Hibiscus rosa-sinensis L. and host plants, Cleome spinosa L., Dregea volubilis (Linn. $f$.) Benth. ex Hook. $f$. and Parsonsia laevigata (Moon) Alston, were analyzed by automatic thermal desorption-gas chromatography-mass spectrometry process (ATD-GC-MS). Of the three nectar plants, the most dominant components were terpenes, which total content exceeded $60 \%$, together with eucalyptol with higher content. Also there were some hydrocarbons, alcohols and aromatic compounds detected in the three nectar plants. Host plant volatiles presented a different composition. C. Spinosa volatiles were mainly composed of terpenoids (36.35\%), aldehydes $(29.07 \%)$, ethers $(10.48 \%)$ and acids $(9.15 \%)$. D. volubilis volatile compounds were mainly esters $(21.03 \%)$, next were terpenoids $(19.53 \%)$. P. laevigata volatiles were composed mainly of aldehydes $(32.2 \%)$ and esters $(19.41 \%)$.
\end{abstract}

Key Words: Volatile components, Butterfly, Nectar plants, Host plants, ATD-GC-MS.

\section{INTRODUCTION}

Butterflies are insects belonged to the Rhopalocera lepidoptera. Butterflies are also one kind of pollinators, most of which not only have high ornamental value but also play an important role in maintaining the ecological balance of the nature ${ }^{1}$.

Plant volatiles are produced and emitted by plants during growth and metabolism processes. Plant volatile components are short-chain hydrocarbons and their derivatives such as terpenes, alcohols, esters, acids, aldehydes, ketones and aromatic compounds etc. ${ }^{2-4}$. Some of those compounds can transmit chemical information in nature, which can regulate behaviours of insects, such as food and host recognition ${ }^{5-7}$. So it is necessary to study volatiles of butterfly host plants and nectar plants for its population reproduction.

The isolation of volatile components can be carried out by several methods i.e., liquid solvent extraction ${ }^{8}$, steam distillation $^{9}$, supercritical fluid extraction $(\mathrm{SFE})^{9}$, solid phase microextraction (SPME) $)^{10}$ and thermal desorption ${ }^{11}$. The thermal desorption method can be carried out automatically (automatic thermal desorption, ATD) on-line with the gas chromatography-mass spectrometry process (GC-MS). Comparing with the first four methods, the last method is simple, accurate, and can determine plants volatiles in vivo. L. camara, V. trifolia and H. rosa-sinensis are nectar plants of some common ornamental butterflies such as Tirumala limniace, Danaus chrysippus and Euploea core ${ }^{12}$ and C. Spinosa, D. volubilis and $P$. laevigata are their host plants ${ }^{13}$. In this paper, plants volatiles in vivo were isolated using the thermal desorption method and then analyzed by ATD-GC-MS.

\section{EXPERIMENTAL}

Nectar plants, flowering L. camara, V. trifolia and H. rosasinensis, were planted in Yuanjiang Experimental Station, Chinese Academy of Forestry (Yunnan, China) in November 2010. Host plants, living C. Spinosa, D. volubilis and P. laevigata, were also planted in Yuanjiang experimental station in November 2010 .

Isolation of volatile components: The flowers or parts of the plant in natural state were putted in one closed, clean sampling bag. Volatile compounds was pumped by an air pump and collected by the sampling tube with adsorbents Tenax TA (0.2 g, 60-80 mesh, Perkin-Elmer). The collection time was 20 min. Sampling tubes were sealed and stored at low temperature $\left(4^{\circ} \mathrm{C}\right)$, ready for automatic thermal desorption and GC-MS analysis.

Automatic thermal desorption (ATD) conditions: Samples were desorbed using a commercial automatic thermal desorption system (Turbomatrix 650, Perkin-Elmer). The desorption temperature of sampling tube was at $260{ }^{\circ} \mathrm{C}$ for $10 \mathrm{~min}$. A flow of 
helium $\left(25 \mathrm{~mL} \mathrm{~min}^{-1}\right)$ transferred the desorbed substances into a cold trap (at $-30^{\circ} \mathrm{C}$, packed with Tenax TA), with a $15 \mathrm{~mL}$ $\mathrm{min}^{-1}$ inlet split. After the desorption period, the cold trap was rapidly heated $\left(40{ }^{\circ} \mathrm{C} \mathrm{s}^{-1}\right)$ to $300{ }^{\circ} \mathrm{C}(5 \mathrm{~min})$ in order to inject the sample as a narrow band into the chromatographic column, with a $20 \mathrm{~mL} \mathrm{~min}^{-1}$ outlet split. Total split ratio was about 22:1.

GC-MS conditions: GC-MS analysis was performed on a Perkin-Elmer Clarus 600 GC-MS instrument equipped with a DB-5 fused silica column $(30 \mathrm{~m} \times 0.25 \mathrm{~mm}, 0.25 \mu \mathrm{m}$ film thickness). Column temperature was initially kept at $40{ }^{\circ} \mathrm{C}$ for $2 \mathrm{~min}$, then increased to $130{ }^{\circ} \mathrm{C}$ at a rate of $6{ }^{\circ} \mathrm{C} \mathrm{min}{ }^{-1}$, held for $5 \mathrm{~min}$ and finally raised to $280{ }^{\circ} \mathrm{C}$ at $15^{\circ} \mathrm{C} \min ^{-1}$ for $5 \mathrm{~min}$. Helium was used as the carrier gas at the constant flow of 1.5 $\mathrm{mL} \mathrm{min}^{-1}$. Mass spectra were recorded in EI mode with a 29500 amu scan range, scan time $0.2 \mathrm{~s}$. Interface temperature $250^{\circ} \mathrm{C}$; ion source temperature $220^{\circ} \mathrm{C}$; ionization voltage $70 \mathrm{eV}$.

Identification of volatile components: Peak identification was accomplished by comparison of the mass spectra with those stored on the GC-MS databases (NIST 08 and Wiley 2000) and reported in the literature. Relative percent of compositions was directly calculated by peak areas from reconstructed total ion current (TIC) trace using the area normalization method.

\section{RESULTS AND DISCUSSION}

Volatile components of nectar plants, $L$. camara, $V$. trifolia and $\boldsymbol{H}$. rosa-sinensis: The identified components and their percentages of nectar plants are given in Table-1 according to their elution order on a DB-5 column. Of the three nectar plants, the most dominant components were terpenes, which total contents exceeded $60 \%$. Terpenes of $L$. camara were diverse, including 3 -carene $(15.15 \%), \beta$-phellandrene $(7.49 \%)$, $\alpha$-caryophyllene $(6.43 \%)$ and limonene $(5.90 \%)$ etc. The main terpenes of $V$. trifolia was $\alpha$-pinene $(23.87 \%)$, together with sabinene $(18.76 \%), \alpha$-phellandrene $(6.60 \%)$ and $\beta$ pinene $(6.03 \%)$. The most abundant terpene compounds of H. rosa-sinensis was limonene $(41.42 \%)$ and next was $\beta$ myrcene $(8.17 \%)$. Many kinds of terpenes, such as $\beta$ phellandrene, caryophyllene, limonene, had the special odour, which could attract insects. Eucalyptol was present in the three nectar plants with higher contents, $11.39 \%$ in L. camara, $22.20 \%$ in V. trifolia and $12.37 \%$ in H. rosa-sinensis. Also there were some hydrocarbons, alcohols and aromatic compounds detected in the three nectar plants, including $p$-cymene $(17.55 \%)$ in $L$. camara and others with a small amounts. Most of those compounds had fragrant odour and were the ingredients of spices.

Volatile components of host plants, C. Spinosa, $D$. volubilis and $P$. laevigata: The main volatile compositions of the determined host plants were different (Table-2). C. Spinosa volatiles were mainly composed of terpenoids $(36.35 \%)$, aldehydes $(29.07 \%)$, ethers $(10.48 \%)$ and acids $(9.15 \%) . D$. volubilis volatile compounds were mainly esters $(21.03 \%)$, including pentyl methoxyl acetate $(7.16 \%)$, isopentyl acetate (4.15\%), ethyl hexanoate (3.99\%), isobutyl acetate $(3.53 \%)$ and hexyl acetate $(2.20 \%)$ and next were terpenoids $(19.53$ $\%)$, particularly $\alpha$-pinene (13.98\%). P. laevigata volatiles were composed mainly of aldehydes $(32.2 \%)$, particularly nonanal $(17.03 \%)$ and decanal $(7.81 \%)$ and esters $(19.41 \%)$, particularly isopentyl acetate $(6.69 \%)$ and ethyl hexanoate $(6.03 \%)$.
TABLE-1

VOLATILE COMPONENTS AND RELATIVE PER CENT

OF FLOWERS OF $L$. camara, $V$. trifolia AND $H$. rosasinensis FROM NECTAR PLANTS in vivo

\begin{tabular}{|c|c|c|c|c|}
\hline \multirow{2}{*}{ Compounds } & & \multicolumn{3}{|c|}{$\begin{array}{c}\text { Relative per cent of } \\
\text { volatiles of flowers }(\%)\end{array}$} \\
\hline & & $\begin{array}{c}L . \\
\text { camara }\end{array}$ & $\begin{array}{c}\text { V. } \\
\text { trifolia } \\
\end{array}$ & $\begin{array}{l}\text { H. rosa- } \\
\text { sinensis }\end{array}$ \\
\hline \multirow{16}{*}{ Terpenes } & $\alpha$-Phellandrene & 2.45 & 6.60 & 2.84 \\
\hline & $\alpha$-Pinene & 4.8 & 23.87 & 1.24 \\
\hline & Camphene & 2.64 & 0.18 & - \\
\hline & Sabinene & - & 18.76 & 9.61 \\
\hline & $\beta$-Phellandrene & 7.49 & - & - \\
\hline & $\beta$-Pinene & 4.24 & 6.03 & 0.70 \\
\hline & $\beta$-Myrcene & 2.14 & - & 8.17 \\
\hline & 3-Carene & 15.15 & - & - \\
\hline & 4-Carene & 2.04 & - & - \\
\hline & Limonene & 5.90 & - & 41.42 \\
\hline & Terpinene & - & 4.14 & \\
\hline & Terpinolene & - & 3.34 & 4.42 \\
\hline & Copaene & 2.04 & - & - \\
\hline & $\beta$-caryophyllene & 4.01 & - & - \\
\hline & $\alpha$-caryophyllene & 6.43 & - & - \\
\hline & $\begin{array}{l}\text { 1-Methyl-4-(1- } \\
\text { methylethyl)-1,4- } \\
\text { cyclohexadiene }\end{array}$ & 2.89 & - & - \\
\hline \multirow{7}{*}{ Alcohols } & Eucalyptol & 11.39 & 22.20 & 12.37 \\
\hline & 1,3-Butandiol & 3.07 & - & - \\
\hline & 3-Hexen-1-ol & 2.70 & - & 1.17 \\
\hline & 3-Methylbutanol & - & 3.95 & - \\
\hline & 1-Octen-3-ol & - & - & 1.5 \\
\hline & 3-Nonen-1-ol & - & - & 0.63 \\
\hline & Linalool & 0.23 & - & - \\
\hline \multirow{3}{*}{$\begin{array}{l}\text { Aromatic } \\
\text { compounds }\end{array}$} & $p$-Cymene & 17.55 & 3.22 & - \\
\hline & $o$-Cymene & - & - & 1.60 \\
\hline & Benzaldehyde & - & - & 0.23 \\
\hline \multirow{3}{*}{$\begin{array}{l}\text { Hydro- } \\
\text { carbons }\end{array}$} & $\begin{array}{l}\text { 2,3-Epoxy-2- } \\
\text { methylbutane }\end{array}$ & - & 4.04 & - \\
\hline & Cyclopentane & - & - & 3.59 \\
\hline & Octane & - & - & 0.31 \\
\hline Esters & cis-3-Hexenyl acetate & - & - & 1.72 \\
\hline
\end{tabular}

\section{TABLE-2}

VOLATILE COMPONENTS AND RELATIVE PER CENT OF C. spinosa, $D$. volubilis AND P. laevigata FROM HOST PLANTS in vivo

\begin{tabular}{|c|c|c|c|c|}
\hline \multirow{2}{*}{ Compounds } & & \multicolumn{3}{|c|}{$\begin{array}{c}\text { Relative per cent of } \\
\text { volatiles of hostplants }(\%)\end{array}$} \\
\hline & & $\begin{array}{c}C . \\
\text { spinosa } \\
\end{array}$ & $\begin{array}{c}D . \\
\text { volubilis }\end{array}$ & $\begin{array}{c}P . \\
\text { laevigata }\end{array}$ \\
\hline \multirow{6}{*}{ Terpenes } & 1-Octene & - & 1.71 & 0.87 \\
\hline & $\alpha$-Pinene & 21.87 & 13.98 & 7.01 \\
\hline & Limonene & 0.70 & 1.66 & 1.42 \\
\hline & Ocimene & - & 2.18 & - \\
\hline & Copaene & 1.15 & - & - \\
\hline & Caryophyllene & 12.63 & - & - \\
\hline \multirow{5}{*}{ Aldehydes } & 2-Methyl pentanal & 20.83 & - & 1.73 \\
\hline & Heptanal & - & - & 1.46 \\
\hline & Octanal & 0.84 & 0.85 & 4.17 \\
\hline & Nonanal & 3.71 & 3.54 & 17.03 \\
\hline & Decanal & 3.69 & 1.79 & 7.81 \\
\hline \multirow{6}{*}{ Esters } & Pentyl methoxyl acetate & - & 7.16 & - \\
\hline & Isobutyl acetate & - & 3.53 & 2.37 \\
\hline & Isopentyl acetate & - & 4.15 & 6.69 \\
\hline & Ethyl hexanoate & - & 3.99 & 6.03 \\
\hline & 3-Hexenyl acetate & 1.81 & - & - \\
\hline & Hexyl acetate & - & 2.20 & 4.32 \\
\hline
\end{tabular}




\begin{tabular}{|c|c|c|c|c|}
\hline \multirow{2}{*}{ Compounds } & & \multicolumn{3}{|c|}{$\begin{array}{c}\text { Relative per cent of } \\
\text { volatiles of hostplants (\%) }\end{array}$} \\
\hline & & $\begin{array}{c}C . \\
\text { spinosa }\end{array}$ & $\begin{array}{c}D . \\
\text { volubilis }\end{array}$ & $\begin{array}{c}P . \\
\text { laevigata }\end{array}$ \\
\hline \multirow{4}{*}{ Alcohols } & Eucalyptol & - & 3.20 & 3.37 \\
\hline & 3-Hexen-1-ol & - & - & 1.82 \\
\hline & 2-Methylundecanol & 3.39 & - & - \\
\hline & 2-Decen-1-ol & - & - & 1.02 \\
\hline Ethers & $\begin{array}{l}\text { 2-(2-Butoxyethoxy) } \\
\text { ethanol }\end{array}$ & 10.48 & 7.56 & 6.93 \\
\hline \multirow{3}{*}{$\begin{array}{l}\text { Hydro- } \\
\text { carbons }\end{array}$} & Pentane & - & 3.28 & 1.99 \\
\hline & $\begin{array}{l}\text { 2-Ethenyl-1,1-dimethyl- } \\
\text { 3-methylenecyclohexane }\end{array}$ & - & 3.72 & - \\
\hline & pentadecane & - & - & 0.84 \\
\hline \multirow{2}{*}{$\begin{array}{l}\text { Aromatic } \\
\text { compounds }\end{array}$} & Ethenyl benzene & - & - & 3.82 \\
\hline & Naphthalene & - & - & 0.97 \\
\hline Acids & Acetic acid & 9.15 & - & - \\
\hline
\end{tabular}

\section{ACKNOWLEDGEMENTS}

The authors acknowledged the financial support of the Special Fund Project for Fundamental Scientific Affairs, Research Institute of Resources Insects, CAF (No. Riricaf 200903Z).

\section{REFERENCES}

1. P. Chai, Biol. J. Linn. Soc., 59, 37 (1996).

2. A. Guenther, C.N. Hewitt, D. Erickson, R. Fall and C. Geron, J. Geophys. Res., 100, 8873 (1995).

3. J. Kesselmeier and M. Staudt, J. Atoms. Chem., 33, 23 (1999).

4. M. Lerdau, A. Guenther and R. Monson, Bioscience, 47, 373 (1997).

5. R.R. Heath, P.J. Landolt and R. Dueben, Environ. Entomol., 21, 854 (1992).

6. K. Honda, H. Omura and N. Hayashi, J. Chem. Ecol., 24, 2167 (1998).

7. J.A. Pickett and J.W. Stephenson, J. Chem. Ecol., 6, 435 (1980).

8. W.M. Coleman, J. Essent. Oil Res., 4, 345 (1992).

9. S.B. Hawthorne, M.L. Riekkola, K. Serenius, Y. Holm, R. Hiltunen and K. Hartonen, J. Chromatogr. A, 634, 297 (1993).

10. C.-F. Yang, Y.-Q. Huang and K. Yuan, Asian J. Chem., 25, 5051 (2013).

11. C. Yaozu, L. Zhaolin, X. Dunyuan and Q. Limin, Anal. Chem., 59, 744 (1987).

12. V. Yiu, Hong Kong Entomol. Bull., 1, 38 (2009).

13. D.W. Li, Sci. Educ. Mon., 277, 2 (1994). 